\title{
Determination of regional and central circulation times by the ascorbate dilution method
}

\author{
P. Bopp, P. C. Fournet, P. R. Moret, and P. W. Duchosal \\ From the Centre de Cardiologie, University Hospital, Geneva, Switzerland
}

The usefulness of the ascorbate dilution method in demonstrating intracardiac shunts and valvular incompetence is known. The ascorbate technique can also be applied to the determination of the transit time of regional vascular beds such as the coronary and the renal systems. Furthermore, the determination of central circulation times may be helpful in the diagnosis of caval obstruction. The method is safe, simple, inexpensive, and reliable.

The introduction by Clark and Bargeron (I959a) of the platinum electrode catheter has proved to be a major advance in the detection of small intracardiac shunts with hydrogen and with ascorbic acid. Several investigators have since confirmed the sensitivity and the reliability of these tests (Frommer, Pfaff, and Braunwald, 196I; Kaplan et al., 196I ; Klussmann and Hardewig, 1964; Levy et al., 1967; Nixon et al., 1962; Rotem and Miller, 1967). Ascorbate curves can also help in the assessment of valvular regurgitation (Schlant et al., 1962). The determination of regional and central transit times offers another field of application of the ascorbate method.

\section{Subjects and methods}

In contact with platinum, ascorbic acid is oxidized; electrons are liberated, and the current thus produced may be registered by connecting the proximal end of the intracardiac electrode catheter $^{1}$ to a recorder through a pre-amplifier. A standard electrocardiographic electrode attached to one of the patient's legs is used as a reference.

Ascorbic acid was injected in doses of roo$200 \mathrm{mg}$. The determination of the coronary transit time was made by injecting ascorbic acid into the aorta, above the valve, through a retrograde catheter, and by detecting the appearance of the indicator in the coronary sinus with a second catheter provided with a platinum electrode. The moment of injection was recorded manually (Fig. I). The coronary transit time was measured in ro subjects whose ages ranged from 17 to $4 \mathrm{I}$ years (mean 29 years); 2 of these had normal heart findings. Among the other 8 people, 3 suffered from mitral stenosis, I from aortic valvular disease, and I had an atrial septal defect; of the

Received 9 February 1970.

1 U.S. Catheter and Instrument Corp., Glens Falls, New York, U.S.A. remaining 3 patients, I showed combined mitralaortic disease, I had endocardial fibro-elastosis, and $I$ had idiopathic atrial fibrillation (Table $I$ ).

The renal transit time is determined similarly by injecting ascorbate into the renal artery and by detecting the appearance of the indicator in the renal vein (Fig. 2 and 3). Bilateral renal transit times were measured in 5 subjects whose ages ranged from 17 to 42 years (mean 28 years). Two subjects were healthy and 3 patients had mitral stenosis but were not in heart failure (Table 2).

In order to measure central circulation times, ascorbic acid was injected into the subclavian veins or into the inferior vena cava, and its appearance was detected by means of an intra-arterially (femoral artery) positioned platinum stylet, introduced by percutaneous Seldinger puncture. Central circulation times were studied in 5 patients suffering from pericarditis (I case) and from noncardiac ailments (4 cases).

FIG. I Determination of the coronary transit time by the ascorbate method; upslope starts 5.5 seconds after injection (i).

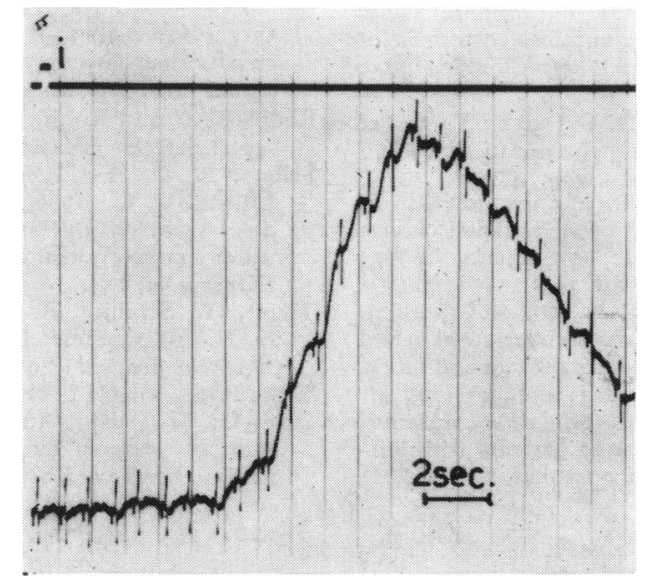


TABLE I Coronary transit time

\begin{tabular}{|c|c|c|c|c|c|c|c|c|c|}
\hline Patient & $\begin{array}{l}\text { Age } \\
(y r .)\end{array}$ & Diagnosis & Rhythm & $\begin{array}{l}\text { Cardiac } \\
\text { index } \\
\left(l . / \min . / m .^{2}\right)\end{array}$ & $\begin{array}{l}L V \\
\text { end-diastolic } \\
(\mathrm{mm} . \mathrm{Hg})\end{array}$ & $\begin{array}{l}\text { Blood pre } \\
\text { (mm.Hg) } \\
\text { Syst./diast }\end{array}$ & Msure & $\begin{array}{l}\text { Cardiac trc } \\
\text { time (sec.) }\end{array}$ & Meansit \\
\hline C.L. & 19 & Normal & Sinus & 4.9 & 6 & $135 / 90$ & IIO & $\left\{\begin{array}{l}4-4-4 \\
3 \cdot 5\end{array}\right.$ & $3 \cdot 9$ \\
\hline $\begin{array}{l}\text { T.P. } \\
\text { S.M. }\end{array}$ & $\begin{array}{l}17 \\
20\end{array}$ & $\begin{array}{l}\text { Normal } \\
\text { Mitral stenosis }\end{array}$ & $\begin{array}{l}\text { Sinus } \\
\text { Sinus }\end{array}$ & $\begin{array}{l}3 \cdot 3 \\
5 \cdot 3\end{array}$ & $\begin{array}{l}6 \\
7\end{array}$ & $\begin{array}{l}105 / 70 \\
120 / 75\end{array}$ & $\begin{array}{l}82 \\
87\end{array}$ & $4-5-5$ & $\begin{array}{l}4 \cdot 8 \\
3 \cdot 0\end{array}$ \\
\hline M.L. & 26 & Mitral stenosis & Sinus & $2 \cdot 3$ & 8 & $114 / 70$ & 85 & $\left\{\begin{array}{l}3 \cdot 5-4 \\
4-3 \cdot 5\end{array}\right.$ & $3 \cdot 8$ \\
\hline G.J. & 35 & Mitral stenosis & Sinus & $3 \cdot 6$ & 8 & $115 / 75$ & 95 & $\left\{\begin{array}{l}5-5 \cdot 5 \\
5\end{array}\right.$ & $5 \cdot 2$ \\
\hline $\begin{array}{l}\text { L.M. } \\
\text { B.F. }\end{array}$ & $\begin{array}{l}38 \\
28\end{array}$ & $\begin{array}{l}\text { Atrial septal defect } \\
\text { Aortic insufficiency } \\
\text { and stenosis }\end{array}$ & $\begin{array}{l}\text { Sinus } \\
\text { Sinus }\end{array}$ & $\begin{array}{l}2 \cdot 0 \\
4 \cdot 5\end{array}$ & $\begin{array}{l}\text { IO } \\
\text { I2 }\end{array}$ & $\begin{array}{l}100 / 70 \\
120 / 70\end{array}$ & $\begin{array}{l}80 \\
85\end{array}$ & $\begin{array}{l}15 \\
6 \\
5 \cdot 5\end{array}$ & $\begin{array}{l}6 \cdot 0 \\
5 \cdot 5\end{array}$ \\
\hline A.M. & 37 & $\begin{array}{l}\text { Endocardial fibro- } \\
\text { elastosis }\end{array}$ & Sinus & $1 \cdot 5$ & 22 & $100 / 60$ & 70 & $5 \cdot 5-5 \cdot 5$ & $5 \cdot 5$ \\
\hline S.M. & 34 & $\begin{array}{l}\text { Mitral stenosis and } \\
\text { insufficiency, and } \\
\text { aortic insufficiency }\end{array}$ & Sinus & $1 \cdot 5$ & 22 & $100 / 45$ & 72 & $\left\{\begin{array}{l}7-7-6 \cdot 5 \\
7-6 \cdot 5 \\
6 \cdot 5-6 \cdot 5\end{array}\right.$ & $6 \cdot 7$ \\
\hline H.P. & $4 I$ & Idiopathic fibrillation & Fibrillation & $3 \cdot 5$ & 7 & $104 / 69$ & $8 I$ & $8-7 \cdot 5$ & $7 \cdot 8$ \\
\hline
\end{tabular}

\section{Results}

Twenty-eight determinations of coronary transit time were carried out (Table I). As many as 7 measurements were made in the same patient; the mean transit time in the first 8 cases was $4.7 \mathrm{sec}$. (range 3-6 sec.). There was a good reproducibility of the curves, the largest variation not exceeding $0.5 \mathrm{sec}$. in the same subject. It is of interest to note that two patients had somewhat longer

FIG. 2 Renal angiogram showing one catheter positioned in the renal artery for injection of ascorbic acid and a second, platinum-tipped, catheter in the renal vein for its detection.

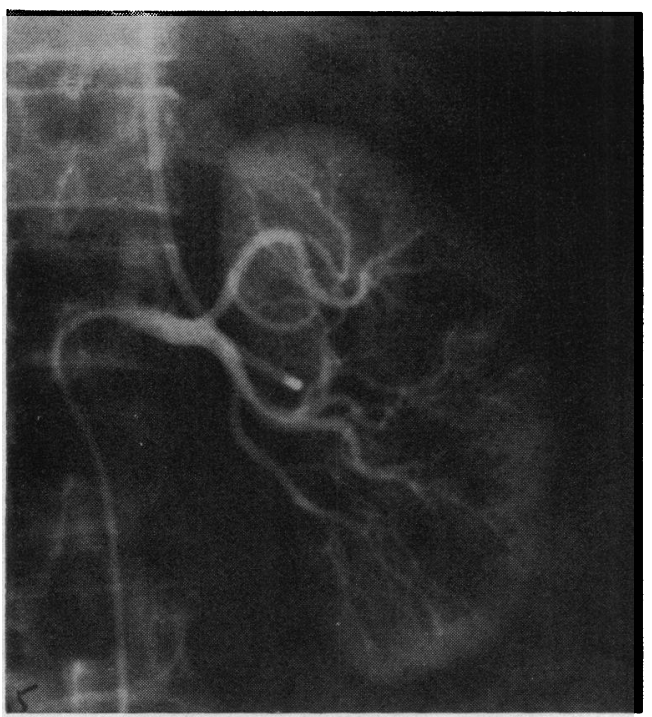

coronary circulation times ( 6.7 and $7.8 \mathrm{sec}$.); one of these showed raised left ventricular end-diastolic pressures and the other had atrial fibrillation; however, another subject who also had raised left ventricular enddiastolic pressures and low cardiac output,

FIG. 3 Determination of the renal transit time; upslope starts 2.0 seconds after injection (i).

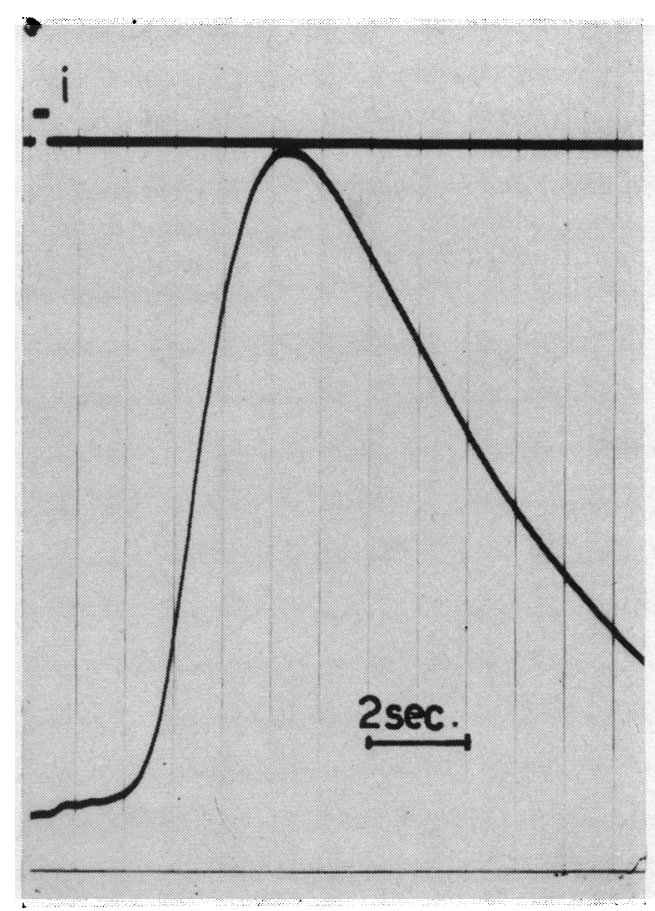


TABLE 2 Renal transit time

\begin{tabular}{|c|c|c|c|c|c|c|c|c|c|}
\hline Patient & $\begin{array}{l}\text { Age } \\
(y r .)\end{array}$ & Diagnosis & $\begin{array}{l}\text { Cardiac index } \\
\left(\text { l. } / \text { min. } / m^{2}\right)\end{array}$ & $\begin{array}{l}\text { Blood pressur } \\
\text { Syst./diast. }\end{array}$ & $e \underset{\text { Mean }}{(m m . H g)}$ & $\begin{array}{l}\text { Renal tran } \\
\text { Right }\end{array}$ & $\begin{array}{l}\text { sit time } \\
\text { Mean }\end{array}$ & $\begin{array}{l}(\mathrm{sec} .) \\
\text { Left }\end{array}$ & Mean \\
\hline L.V. & 42 & Normal & $3 \cdot 6$ & $140 / 90$ & II2 & $2-2$ & $2 \cdot 0$ & $\left\{\begin{array}{l}2-2-2 \cdot 5 \\
2 \cdot 5-2-2\end{array}\right.$ & $2 \cdot 3$ \\
\hline S.H. & 30 & Normal & 3.9 & $110 / 70$ & 83 & $3-2-2$ & $2 \cdot 3$ & $\left\{\begin{array}{l}3-3-4-4 \\
3 \cdot 5\end{array}\right.$ & 3.5 \\
\hline M.G. & 33 & Mitral stenosis & $5 \cdot 0$ & $130 / 80$ & 97 & $\left\{\begin{array}{l}1 \cdot 5-2 \cdot 5 \\
2 \cdot 5\end{array}\right.$ & $2 \cdot 2$ & $\left\{\begin{array}{l}2 \cdot 5-3-3 \\
3-3-2 \cdot 5\end{array}\right.$ & $2 \cdot 8$ \\
\hline $\begin{array}{l}\text { H.J.M. } \\
\text { A.A. }\end{array}$ & $\begin{array}{l}17 \\
19\end{array}$ & $\begin{array}{l}\text { Mitral stenosis } \\
\text { Mitral stenosis }\end{array}$ & $\begin{array}{l}3 \cdot 1 \\
1 \cdot 8\end{array}$ & $\begin{array}{l}120 / 80 \\
110 / 80\end{array}$ & $\begin{array}{l}93 \\
90\end{array}$ & $\begin{array}{l}2 \cdot 5-3-3 \\
4-4\end{array}$ & $\begin{array}{l}2 \cdot 8 \\
4 \cdot 0\end{array}$ & $\begin{array}{l}3-4 \\
2 \cdot 5-2 \cdot 5\end{array}$ & $\begin{array}{l}3.5 \\
2.5\end{array}$ \\
\hline
\end{tabular}

but who was in sinus rhythm, had a shorter transit time $(5.5 \mathrm{sec}$.).

Thirty-four determinations of the renal transit time were performed (Table 2). The right renal transit time was measured 13 times (range $\mathrm{I} \cdot 5-4.0 \mathrm{sec}$; mean $2.6 \mathrm{sec}$.) and the left one $2 \mathrm{I}$ times (range $2 \cdot 0-4.0 \mathrm{sec}$; mean $2.8 \mathrm{sec}$.). The reproducibility was fairly good, the variation not exceeding $\mathrm{I} \cdot 0 \mathrm{sec}$. in the same kidney. Two examples illustrate the usefulness of the ascorbate curves in the study of central circulation times.

Case I A 65-year-old man was known to have suffered from a mediastinal cyst 20 years earlier. There was no visible calcification on the present chest $x$-ray. The intracardiac pressures were found to be raised (right atrium mean $25 \mathrm{~mm} . \mathrm{Hg}$; right ventricle $70 / 25 \mathrm{~mm} . \mathrm{Hg}$; pulmonary artery $70 / 25 \mathrm{~mm} . \mathrm{Hg}$ (mean 4I); pulmonary wedge $24 \mathrm{~mm} . \mathrm{Hg}$ ) and to show a characteristic plateaulike pattern. The injection of ascorbate into the

FIG. 4 Determination of central circulation time with ascorbate; injection into (a) right, and (b) left subclavian veins, and (c) inferior vena cava, with detection of indicator in the femoral artery. The three transit times are similar ( 15 sec.).

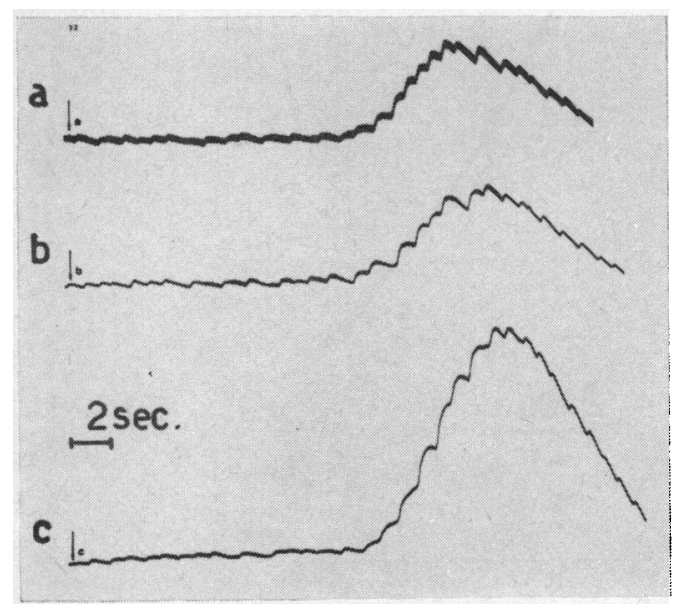

right and left subclavian veins, and into the inferior vena cava, with the detection of the indicator in the femoral artery showed that central circulation times were all within the same range (I5 sec.) (Fig. 4), that is at the upper limit of normal. A diagnosis of chronic constrictive pericarditis was made. The absence of any localized venous obstruction was confirmed by cavography.

Case 2 A 72-year-old woman was suffering from a superior vena cava obstructive syndrome, the venous distension being most apparent on the left side. A mediastinal tumour was revealed by $x$-ray. Ascorbate dilution curves showed a delay when the indicator was injected into the left axillary vein (Fig. 5). The existence of left innominate vein obstruction was confirmed by angiography (Fig. 6).

\section{Comments}

The ascorbate dilution technique can be used successfully for the determination of regional transit times. Gorlin and Storaasli (1956) have

FIG. 5 Determination of central circulation time with ascorbate; injection into (a) left and (b) right axillary vein with detection of indicator in the femoral artery; there is a delay ( 12.0 versus $8.5 \mathrm{sec}$.) when the indicator is injected into the left axillary vein.

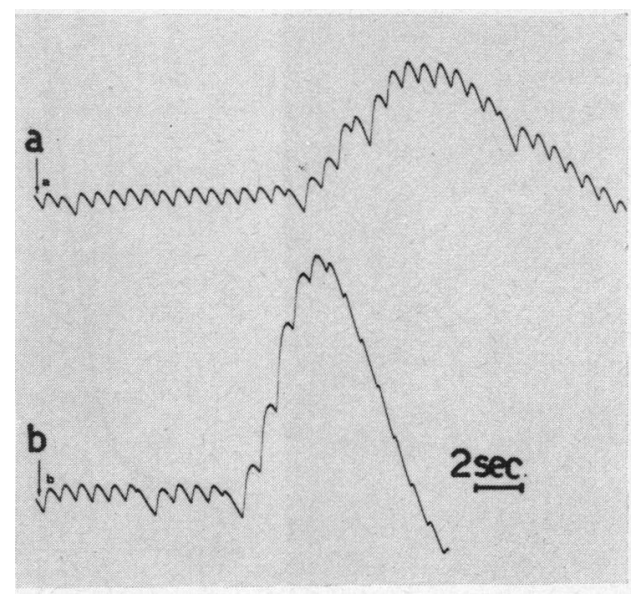




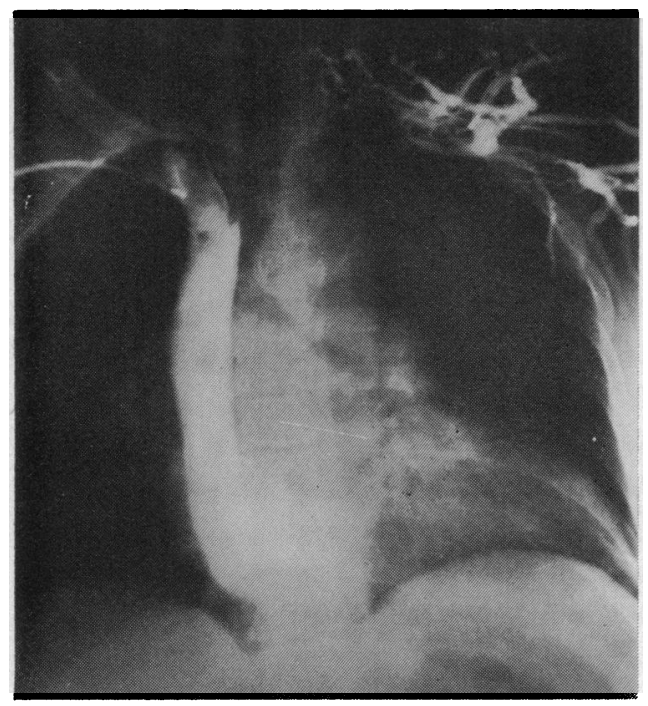

FIG. 6 Superior vena cava angiography; bilateral injection showing obstruction of the left innominate vein.

measured the transcoronary circulation time in 15 subjects by injecting radioactive ${ }^{131} \mathrm{I}$ serum albumin. The appearance of the indicator in the left ventricle and in the coronary sinus was detected by the use of two scintillation counters. These authors report values ranging from 6.5 to II seconds; however, the increasing background radiation may interfere with the accuracy of the determinations. Bernstein et al. (1962) measured the myocardial transit time in anaesthetized dogs with open chest; one electrode was placed at the base of the aorta and the second in the coronary sinus. Using hydrogen as an indicator, these investigators obtained values ranging from 3.2 to $8.2 \mathrm{sec}$., but there were also large differences in the mean arterial pressures (44-r $46 \mathrm{~mm} . \mathrm{Hg}$ ), the higher pressures being generally associated with shorter times.

Our patients were in a satisfactory steady state and had more comparable mean arterial pressures (range 70-I IO mm.Hg). Our results correspond to the findings of Clark and Bargeron (1959b) who, using the electrode catheter, indicate that hydrogen appears in the coronary sinus after 5 seconds.
Gorlin and Storaasli (1956) have shown the close relation between coronary blood flow and transit time. It might be of further interest to study separately right and left coronary transit times, by selective injection of ascorbate into each artery.

Similarly, the application of the ascorbate method to the determination of renal circulation time might yield information about flow patterns in patients with kidney disease.

It is likely that the ascorbate method could also be applied to other vascular territories such as the brain system.

\section{References}

Bernstein, H., Skelton, R. B. T., Gold, H., Irving, D. W., and Corday, E. (I962). Myocardial transit time: A new technic for evaluating coronary circulation. I. Effect of systemic blood pressure. American fournal of Cardiology, 9, 777.

Clark, L. C., and Bargeron, L. M. (1959a). Left-toright shunt detection by an intravascular electrode with hydrogen as an indicator. Science, r30, 709.

$\longrightarrow$, and - (1959b). Detection and direct recording of left-to-right shunts with the hydrogen electrode catheter. Surgery, 46, 797.

Frommer, P. L., Pfaff, W. W., and Braunwald, E. (196r). The use of ascorbate dilution curves in cardiovascular diagnosis. Circulation, 24, 1227.

Gorlin, R., and Storaasli, J. P. (1956). Transcoronary circulation time: A new method of evaluating the coronary vascular system (Abstract). Circulation, I4, 943.

Kaplan, S., Clark, L. C., Edwards, F. K., Gallaher, M. E., and Fox, R. P. (196I). Localization of right to left shunts with an intravascular polarographic anode sensitive to ascorbic acid. American fournal of Cardiology, 8, 659.

Klussmann, F. W., and Hardewig, A. (1964). Uber die Verwendung von Ascorbinsäure-Verdünnungskurven in der kardiologischen Diagnostik. Zeitschrift für Kreislaufforschung, 53, 249.

Levy, A. M., Monroe, R. G., Hugenholtz, P. G., and Nadas, A. S. (1967). Clinical use of ascorbic acid as an indicator of right-to-left shunt; with a note on other applications. British Heart fournal, $29,22$.

Nixon, P. G. F., Snow, H. M., Hepburn, F., Hay, G., and Addyman, R. (1962). The ascorbic acid indicator-dilution technique. In Proceedings of the British Cardiac Society. British Heart fournal, 24, 793 .

Rotem, C. E., and Miller, H. (1967). Diagnostic applications of the platinum-electrode catheter. British Heart Fournal, 29, 232.

Schlant, R. C., Edwards, K. F., Rawls, W. J., Brinsfield, D. E., and Shuford, W. H. (I962). New method for estimation of aortic regurgitation (Abstract). Circulation, 26, 782. 